\title{
The Students Are Not All Right: \\ LGBT+ Student Lives Beyond the Happy Normal and the Suicidal Exception ${ }^{1}$ Jeffrey W. Lockhart
}

[Title Slide]

Before we start I want to thank the Centre for Gender Studies for graciously offering to host this talk, and Fordham University for funding part of the research I am about to present.

[New Slide - IGB]

On September 21, 2010, prominent gay advice columnist Dan Savage and his husband Terry uploaded a video to YouTube². "High school was bad,” Dan begins as they each tell their stories: “I was picked on because, you know, I liked musicals and I was obviously gay." "People were really cruel to me. I was bullied a lot.” One minute into the video, Terry says "Honestly, things got better the day I left high school. I didn’t see the bullies every day.” Dan promises their teenage audience that "It gets better, and your life can get great, can get awesome. Your life can be amazing, but you have to tough this period out, you have to live your life so that you're around for it to get amazing.”

The very next night, Rutgers University student Tyler Clementi tragically took his own life, after his roommate tweeted about spying on Tyler in an intimate situation with another man. The extensive media coverage of Tyler's death made harassment in colleges difficult to ignore.

These two events highlight what I call the "Happy Normal” and the "Suicidal Exception” of LGBT life in American colleges. College in the US is generally thought of as a sexually progressive place, where sexual and gender minority (SGM) youth can trade conservative families and high school bullies for liberal administrations and other recently-liberated peers. Although no one denies that some SGM students struggle with mental health and suicidal 1 Talk given at the University of Cambridge Centre for Gender Studies on 4 March, 2015 2 https://www.youtube.com/watch?v=7IcVyvg2Qlo 
thoughts, popular media describe these issues as isolated and exceptional, far removed from the Happy Normal.

For three years I have lead an ongoing study ${ }^{3}$ of SGM college students in universities across North America about their experiences of harassment. What other researchers and I have found is evidence that the story of happy normal college life for SGM students has progressed faster than their lived experience. Neither the Happy Normal nor the Suicidal Exception accurately describes the complicated lives of most SGM students, but the prominence of these myths prevents us from actually working to make those lives better.

\section{A Story of Progress}

[New Slide - Gay Power]

Columbia University was the site of the first official LGB student group, the Student Homophile League (SHL) in 1967, two years before the Stonewall riots. Within 4 years, there were 175 LGB student groups across the country. Brett Beemyn's 2003 article in the Journal of the History of Sexuality ${ }^{4}$ chronicles how the first few SHL chapters became so successful. Initially, Columbia faced scathing criticism in presses nationwide for approving the group, and getting students to sign up was nearly impossible due to their fears about coming out. Eventually, though, SHL forged alliances with radical black, women's, socialist, and anti-war student groups and changed its name to “Gay Liberation Front.” These coalitions solidified the place of gay liberation as a cause within the larger movement of New Left politics. Gay, and to a lesser extent lesbian and bisexual, students found support and solidarity in a growing array of other student groups.

[New Slide - AIDS Quilt]

3 http://fordhamqueery.org

4 Beemyn, Brett. 2003. "The Silence Is Broken: A History of the First Lesbian, Gay, and Bisexual College Student Groups." Journal of the History of Sexuality 12(2):205-23. 
By 1982, however, the New York Times was running headlines like "New Homosexual Disorder Worries Officials,"” and the situation of gay men had changed dramatically. The disease, variously called "gay cancer,” "gay plague,” "gay-related immune deficiency (GRID)," and "gay compromise system," soon came to be called "acquired immune deficiency syndrome (AIDS).” AIDS remained the primary organizing principle of gay organizations through the mid 90s. Groups like AIDS Coalition to Unleash Power (ACT UP) and the Names Project demanded medical research and public awareness campaigns. By 1996, the number of AIDS-related deaths in the US began to decline sharply. ${ }^{6}$

[New Slide - Prom]

Yet during this period, institutional and legal resources for LGB students grew. The 1980 federal case Fricke v. Lynch ${ }^{7}$ secured their right to take same-sex partners to dances. Seven years later, the last mention homosexuality was removed from the American Psychological Association’s Diagnostic and Statistical Manual. The University of Michigan held the first lavender graduation, a special graduation ceremony honoring lesbian and gay students, in $1995^{\circ}$. Between 1987 and 2000, 27 states joined California in adding sexual orientation to their hate crime laws.

[New Slide - Shepard]

On October 6, 1998, gay University of Wyoming student Matthew Shepard was brutally tortured and left to die. His murder captured national attention and became the subject of numerous films, plays, and books. Activists made his name central to their calls for social and legal change.

5 Altman, Lawrence K. 1982. "New Homosexual Disorder Worries Health Officials.” The New York Times, May 11.

6 https://www.aids.gov/hiv-aids-basics/hiv-aids-101/aids-timeline/ 7 Fricke v. Lynch, U.S. District Court for Rhode Island, May 28, 1980

8 https://spectrumcenter.umich.edu/article/annual-events-and-celebrations 
And change they got. States continued to add sexual orientation to their hate crime laws, and for the first time began including gender identity as well. In 2003’s Lawrence and Garner v. Texas, the Supreme Court of the US overturned laws against sodomy (which still existed in 14 states). That same year, Massachusetts became the first state to declare a right to same sex marriage. In 2009, a law named after Matthew Shepard and James Byrd, Jr. added sexual orientation, gender identity, gender, and disability to the federal definition of hate crimes. Openly LGB people were allowed to serve in the military in 2011. In June 2013, the Supreme court struck down the Defense of Marriage Act, giving federal recognition to same sex marriages. By the end of 2014, 35 states had legalized same sex marriage.

[New Slide - Campus Pride]

Support for SGM students grew in universities, too. In 2004, the Consortium of Higher Education LGBT Resource Professionals boasted in its first annual newsletter that it had nearly 50 campus LGBT resource directors. Today, their website ${ }^{9}$ lists staffed LGBT resource centers at more than 190 campuses. Leading college ranking company Princeton Review has ranked the treatment of homosexual students for over a decade, and in 2005 an organization called Campus Pride began issuing extensive report cards on colleges' resources for SGM students based on the research of Sue Rankin and her collaborators.

Given this story of progress, shouldn’t SGM college students be happy? They have legal protections against discrimination and harassment in the form of Title IX and the Shepard-Byrd Act. They can join ROTC, and most of them can marry. Most of their universities have SGM student groups and events, and many have resource centers as well. College is an opportunity to meet other SGM people and for many, to live apart from their families. Consensual sex, should they chose to have it, is legal. SGM characters have been in mainstream media all their lives. 9 http://www.lgbtcampus.org/ 
This year's freshers were born at the same time Ellen DeGeneres was coming out on Oprah, four years after Angels in America and two years before Will \& Grace. The L Word and Brokeback Mountain both came out before they were ten. During their first year of high school, the It Gets Better Project was launched, resulting in thousands of youtube videos that collectively received tens of millions of views.

\section{Why Tyler?}

\section{[New Slide - Puzzle]}

Despite all this apparent progress for SGM college students, Tyler Clementi tragically took his own life on September 22, 2010. And although his name stands out as an unusual case, the Suicidal Exception to the Happy Normal, a 2008 study $^{10}$ by the Suicide Prevention Resource Center estimates that 30-40\% of SGM youth have attempted suicide at some point.

Unfortunately, Tyler’s experience is not nearly so rare.

We can start to understand why harassment and its detrimental effects are thought of as rare with data from one of the universities in my study. The administration proudly promoted their exit survey data showing that only 3.9\% of all students strongly disagree with the statement, "I feel that the community [here] welcomes everyone regardless of their sexual identity." Although the number of students who feel this way seems small, it's about the same size as the university’s estimated SGM student population. While a correlation like this isn’t evidence, I began to wonder, could it be that SGM students experience hostility that their straight, cisgender peers do not see? What was wrong with the rosy picture painted by the story of progress that not everyone could believe it?

10 Suicide Prevention Resource Center. (2008). Suicide risk and prevention for lesbian, gay, bisexual, and transgender youth. Newton, MA: Education Development Center, Inc. 
Many things are missing from the story of gay progress. AIDS continues to take SGM lives and to be a source of stigma for gay men. And while the number of deaths from AIDS for white men declined sharply after 1996, the US Department of Health and Human Services reports that it remained ten times as deadly for black men. ${ }^{11}$ SGM youth make up $40 \%$ of all homeless youth in the US according to a 2012 study by the Williams Institute ${ }^{12}$, which also found that family rejection was the leading cause of their homelessness. The FBI's latest national hate crimes data counts 1,135 incidents motivated by sexual orientation in $2012^{13}$, making sexual orientation the second leading motive for documented hate crimes, after race. Transgender people face a host of challenges when they seek medical care, including their continuing classification as mentally disordered by the DSM. In many states, SGM people are not protected from employment discrimination. The list goes on.

[New Slide - Dorm]

Even in colleges, the place where "it gets better" for SGM youth, these students often face hostility. Tyler Clementi’s story of being harassed by his roommate, though well publicized, is far from unique. Kyle, a gay sophomore active in SGM student groups, approached me privately several weeks after he participated in my study. He confessed that his roommate had been verbally abusive and had vandalized his property for most of a year because Kyle was gay. He said he hadn't been able to write about his experiences even in my anonymous online study; it was difficult for Kyle to revisit what happened. One in five of Kyle's peers said they experience discrimination or hostility in their dorms, and half of them are not out to their roommates.

11 https://www.aids.gov/hiv-aids-basics/hiv-aids-101/aids-timeline/ 12 Durso, L.E., \& Gates, G.J. (2012). Serving Our Youth: Findings from a National Survey of Service Providers Working with Lesbian, Gay, Bisexual, and Transgender Youth who are Homeless or At Risk of Becoming Homeless. Los Angeles: The Williams Institute with True Colors Fund and The Palette Fund. 13 https://ucr.fbi.gov/hate-crime/2012 
Although cases like Kyle's seem to demand swift, severe intervention by university officials, Kyle, like many others, didn’t report most of the harassment to authorities. And when he did, he begged them not to act. He feared making the abuse worse and being stigmatized as a victim by his peers.

[New Slide- Claire Quote]

Dishearteningly, a number of his peers also express fears that their university would not take them seriously if they reported harassment, or that they would be blamed by officials for what happened to them. One of these students is Claire, a senior who watched as her friend was physically assaulted for their sexuality by another student. In the aftermath of the assault, Claire blames her university, "[t]he people who have educated them [are] responsible. That includes parents, teachers, and professors and administrators... I don't think [my university] will actually change the homophobia on campus. It is ingrained.”

These concerns echo those of students across the US who have recently gained national attention through Title IX investigations and lawsuits over their universities' mishandling of sexual assault cases. They're not isolated to one event or one institution, but rather reflect a broad lack of faith in their colleges among student survivors and advocates.

The problems run deeper than direct aggression like Kyle and Claire experienced. Sam, a junior who identifies as bisexual and queer, says her "roommate went on a rampage about not standing for any of this 'gay and lesbian bullshit' on her campus. As a result, she does NOT know that I am bisexual." Although the incident made her feel "scared" and "like a worthless individual who was unwelcome in the University,” Sam never reported it to dorm staff, whom she's not out to. Although many of the people she spends time with are sexual minorities, Sam is only out to some of her family and close friends. And even though being mostly in the closet 
about her sexuality has protected her from being personally targeted for harassment at her campus in the Northeast, Sam says she's still afraid. Like one in six of her peers, Sam considered leaving her university because she didn’t “feel safe and comfortable” there.

\section{Classrooms with Closets}

[New Slide - Classroom]

Students' concerns extend beyond their rooms. More students felt unsafe and uncomfortable in classrooms and around faculty than almost anywhere else: in their dorms, at work, outside on or off campus. Many progressive faculty members I told were shocked: how could classrooms be so threatening without them realizing it? After all, they had no hostile feelings toward these students, and universities have been notoriously more gay-friendly than general society for half a century. These faculty weren't naive; they had heard of Tyler Clementi and Matthew Shepard, but like most people, they saw their stories as exceptions. Threats to SGM college students, the story goes, take place late at night, in dorm rooms and bars, not in classrooms with professors and a room full of students watching.

The research tells a different story. In their unprecedented 2010 national study ${ }^{14}$ of LGBT people in higher education with Campus Pride, Sue Rankin and her colleagues found that LGBT students, especially trans students and students of color, were significantly less likely to feel comfortable in classrooms than their peers. One of my respondents demonstrates why these students often see hostility where others don't. Rich, a senior who identifies as pansexual and transgender, wrote that after overhearing transphobic remarks class, “I didn’t feel comfortable participating in the discussion.” Since their professor, the classroom's authority figure, allowed these remarks to pass without comment, Rich said there wasn’t a “clear person to report [the

14 Rankin, Susan R., Genevieve Weber, Warren Blumenfeld, and Somjen Frazer. 2010. 2010 State of Higher Education for Lesbian, Gay, Bisexual, and Transgender People. Charlotte. 
hostile language] to,” and, like the vast majority of students in their position, ended up staying quiet.

Small phrases and actions that often feel hostile to minorities but pass largely unnoticed by others are what psychologist Chester Pierce first termed "microaggressions" in $1970^{15}$ while writing about black Americans. They can take many forms in a classroom. Sometimes it's an example that assumes female students will have "boyfriends" or "husbands," or a language exam that "corrects" a student's intentional choice of gender. Other times it is an insensitive remark about SGM political or social issues, or terminology with negative connotations.

Microaggressions can have a strong impact: as one participant put it, "my concentration is killed all of the time, like everyday."

[New Slide - Claire]

And students don't have to actually experience hostility in a class to be affected. Coming out is about what students fear might happen. If they come out and then face harassment or discrimination, they can’t very well go back in time and chose differently. Claire, who I mentioned in the last section, wrote: "I sometimes don't speak up in class when I find something offensive said in the literature, by a student, or by a professor because it might out me or label me as 'that gay/feminist girl' and then the professor or students target me for any issues surrounding the gay or women's movements.” Staying silent means they're engaging their classes less. Even Alex, one of Claire's peers who is out to "everyone" as bisexual and considers herself “more social than average," says that the environment at her university "limits what I feel like I can express in my essays or say in my classes to contribute to discussion if it may be considered too out of the norm.”

15 Pierce, C.M., 1970. Black psychiatry one year after Miami. Journal of the National Medical Association, 62(6), p.471. 
[New Slide - Teaching for Inclusion]

Most students in my research were not out to their faculty, and almost half weren't out to their classmates. The majority of these students were out to some people, usually a combination of friends, family, and roommates. But going to class was like going back into the closet. Although it’s nearly 20 years old, UNC’s 1997 handbook, Teaching for Inclusion ${ }^{16}$, aptly describes the dilemma many SGM students still face: "if they decide it is too dangerous to [come out], they must create a persona in class that fits the heterosexual norm. These students are in the position of having to lie about the normal events in life that any other college student makes the topic of daily conversation, such as how they plan to spend the weekend.”

These effects add up: a 2012 national study of college athletes by Campus Pride ${ }^{17}$ found that students who perceived a hostile campus climate generally did worse academically than those who ranked their campus climate more accepting, a pattern that holds for women and racial minorities as well. Research on this topic has reached a clear consensus that campus climate impacts academic engagement and success, and that the environment in classrooms, laboratories, and offices both shapes and is shaped by overall campus climate.

\section{Conclusions}

[New Slide - Doom]

My point is not that SGM college students are doomed. Far from it. Their lives and experiences are far too complex to be condensed into simple categories like the Happy Normal and the Suicidal Exception. SGM students live in a world where they both face violence and have legal protections from it. Where they can have sex, but they might also be sexually assaulted. Where they can come out openly but also hear others openly use slurs like "fag," 16 Geer, Anne. 1997. "Teaching for Inclusion: Diversity in the College Classroom." in Teaching a Diverse Student Body. UNC-CH Center for Teaching and Learning. 17 Rankin, Susan R. and Daniel Merson. 2012. 2012 LGBTQ National College Athlete Report. 
“dyke," and "tranny.” Where whole books and courses are designed around their identities, while others erase them completely from history and theory. Where they can find community and love as well as rejection and abuse among their peers.

[New Slide - Georgetown/Memorial]

Because they rarely talk about their negative experiences, even with close friends, the image of the Happy Normal SGM college student persists. And when the worst happens, it seems isolated—-the Suicidal Exception—rather than one extreme end of a more general cultural experience shared in different degrees and ways by other SGM students.

[Slide - Carry that Weight]

US campus activism is in the middle of a revival. Student activism around sexual assault has drawn substantial attention to both campus rape culture and administrative failures, prompting the Department of Education to open Title IX investigations at 100 colleges and universities ${ }^{18}$. These issues are not distinct. SGM students can be both perpetrators and victims of sexual assault, sometimes because of their sexual or gender identity. And the spirit and energy of this activism, to oppose sexual harassment and violence, presents us with new resources for talking about the harassment and violence other students face.

18 Anderson, Nick. 2015. "Schools Facing Investigations on Sexual Violence: Now More than 100." The Washington Post, March 4. 